\title{
Potensi Tanaman Sorgum (Sorghum bicolor L.), Azotobacter sp. dan Pseudomonas sp. Sebagai agen biologis dalam proses Fitoremediasi Hidrokarbon minyak bumi
}

\author{
Pujawati Suryatmana'), Alyani Shabrina2), Nadia Nuraniya Kamaluddin1), \\ Betty Natalie Fitriatin ${ }^{1)}$, Reginawanti Hindersah ${ }^{1)}$, dan Mieke Rochimi Setiawati1) \\ 1)Departemen Ilmu Tanah dan Sumberdaya Lahan, Fakultas Pertanian Universitas Padjadjaran \\ 2)Program Studi Magister Ilmu Tanah, Fakultas Pertanian Universitas Padjadjaran \\ Jl. Raya Bandung Sumedang Km 21 Jatinangor
}

Korespondensi: pujawati@unpad.ac.id

\begin{abstract}
Phytoremediation using Sorghum (Sorghum bicolor L.) plant is an alternative green technology to overcome oil polluted soil. Improving of the phytoremediation performance are needed stimulating agent to enhance the rate of hydrocarbon biodegradation and increase the plant growth. One of the bioagent that can act as biostimulant is Azotobacter sp. and Pseudomonas sp., because thouse bioagent can provide elements $N$ and $P$, and phytohormone for sorghum plants. The purpose of this study is to examine the role of Azotobacter sp. and Pseudomonas sp. as a biostimulant for Sorghum bicolor L. in the process of biodegradation of petroleum hydrocarbon in soil system. The factorial randomized block design was used as the experimental design. The treatment consisted of 4 application levels of Azotobacter sp. and 4 levels of application of Pseudomonas sp. The results showed that there was no interaction between Azotobacter sp. and Pseudomonas sp. aplication on the efficiency of hydrocarbon degradation of the population of Azotobacrer spp., Pseudomonas spp. and plant height increase. Azotobacter sp. and Pseudomonas sp. also did not show an increase in value on each test variable. While, the potential of sorghum plants without the application of Azotobacter sp. and Pseudomonas sp. (control treatment) showed the value of the efficiency of biodegradation in the range of values of $60.442 \%-68.165 \%$ during 14 weeks period and not significantly different from other treatments.
\end{abstract}

Keywords: Azotobacter sp., Phytoremediation, hydrocarbons, Pseudomonas sp., Sorghum bicolor L,

\section{PENDAHULUAN}

Sampai saat ini mayoritas masyarakat dunia masih menggunakan minyak bumi untuk memenuhi kebutuhan energinya dalam hampir semua aspek kehidupan. Minyak bumi yang digunakan mulai dari bensin, LPG, minyak gas, solar, dan sebagainya. Melihat pentingnya fungsi dari minyak bumi tersebut, maka eksplorasi dan pengolahan minyak bumi masih terus dilakukan. Hal ini berdampak terhadap produksi limbah minyak bumi sebagai produk sampingan dari kegiatan seperti eksplorasi, pengolahan, transportasi dan mungkin juga terjadi kecelakaan. Dilaporkan bahwa dari ekplorasi dan pengolahan minyak bumi menjadi berbagai produk energi akan dihasilkan 33\% hidrokarbon yang berupa limbah.

Produksi kilang minyak bumi di Indonesia menghasilkan minyak bumi sekitar 1,2 juta barrel per hari yang menghasilkan limbah padat sebanyak 2.833.783,51 barrel pertahun dan $30 \%$ diantaranya adalah limbah berbahaya dan beracun (BPS, 2018). Menurut Kementrian Lingkungan Hidup (2003), limbah minyak bumi akan menimbulkan masalah di lingkungan apabila memiliki kandungan Total Petroleum Hydrocarbon (TPH) lebih besar dari 1\% dan total Polysiclic Aromatic Hydrocarbon (PAH) lebih besar dari 10 ppm. Bahan-bahan ini bila dibiarkan akan merusak ekosistem lingkungan, sedangkan apabila dilakukan pembakaran akan menimbulkan pencemaran udara, dan apabila didaur ulang memerlukan teknologi dan biaya yang tinggi. Oleh karena itu limbah minyak bumi perlu ditanggulangi dengan metode yang tepat dan ramah lingkungan.

Penanggulangan pencemaran minyak bumi dapat dilakukan dengan cara fisika, kimia, dan biologi (Udiharto, 1992). Penanggulangan secara fisika, biasanya dilaksanakan pada langkah awal penanganan, yang bertujuan 
untuk mengisolasi secara cepat penyebaran minyak ke lingkunagn yang lebih luas. Penanggulangan secara kimia dapat dilakukan dengan menggunakan dispersan, sehingga minyak tersebut dapat terdispersi (Doerffer, 1992). Kedua cara ini masih memiliki beberapa kelemahan, yaitu pengoperasiannya yang mahal, dapat mengganggu biota di lingkungan tersebut dan sifatnya tidak mendaur.

Penanggulangan secara biologi merupakan alternatif untuk mengatasi limbah minyak bu$\mathrm{mi}$, tanpa merusak lingkungan dengan memanfaatkan mikroorganisme pendegradasi/pengurai dan tanaman (Udiharto, 1992). Penguraian suatu bahan organik kompleks se-cara biologis menjadi senyawa yang lebih sederhana seperti $\mathrm{CO}_{z}, \mathrm{H}_{2} \mathrm{O}$ dan logam dilakukan melalui aktivitas mikroorganisme disebut biodegradasi (Thomas et. al., 1992). Sedangkan teknik yang menggunakan tanaman untuk menghilangkan zat pencemar secara parsial disebut fitoremediasi (Truu et. al., 2008).

Fitoremediasi merupakan pemanfaatan tumbuhan untuk meminimalisasi, mengurangi dan mendetoksifikasi polutan. Konsep pemanfaatan tumbuhan untuk meremediasi tanah yang terkontaminasi polutan adalah pengembangan dalam teknik pengolahan limbah. Fitoremediasi dapat diaplikasikan pada limbah organik maupun anorganik baik dalam bentuk padat, cair, dan gas. Pada tanah yang ditanami tumbuhan hijau menunjukkan kandungan senyawa kimia polutan organik lebih rendah dibandingkan disekitar tanah yang tidak ditanami tumbuhan hijau (Salt et. al., 1998).

Setiap tanaman memiliki kemampuan yang berbeda-beda sebagai agen fitoremediasi baik itu perannya dalam penyerapan zat toksik, mendegradasi polutan organik, serta kemampuannya untuk tumbuh di lingkungan dengan tingkat toksisitas yang tinggi. Sorgum (Sorghum bicolor L.) memiliki daya adaptasi yang tinggi terhadap lingkungan dengan cekaman polutan dengan toksisitas tinggi, memiliki sistem perakaran serabut, kuat, dan menyebar dalam tanah. Sistem perakaran yang banyak tersebut berfungsi sebagai fitoremediator yang potensial.
Konsep fitoremedaitor untuk hidrokarbon minyak bumi adalah prisip fitostimulasi, yaitu tanaman melepas eksudat akar berupa gula, fenol, asam amino, dan berbagai bahan organik ke dalam lingkungan tanah yang dapat membantu menstimulasi aktifitas mikroba pendegradasi hidrokarbon. Menurut Widyati (2008) eksudat akar yang dihasilkan dari aktivitas sel akar hidup tanaman sorgum diperlukan mikroba serta Petrobacter indigenous sebagai sumber energi dalam proses metabolismenya. Atlas dan Bartha (1998) melaporkan bahwa eksudat akar dapat menarik mikroba mendekati akar dan berasosiasi dengan tanaman serta dapat meningkatkan populasi mikroba menjadi 5-100 kali lebih banyak di daerah rizosfir.

Pada proses degradasi hidrokarbon minyak bumi bakteri, jamur, dan aktinomisetes merupakan agen utama dalam proses bioremediasi senyawa hidrokarbon (Young et. al., 1996). Bakteri menunjukkan kemampuannya dalam metabolisme dan mungkin berperan lebih besar selama proses biodegradasi selama substrat yang tersedia lebih bervariasi secara struktur kimianya. Oleh karena itu, dalam upaya meningkatkan kinerja fitoremediasi limbah minyak bumi selama proses biodegradasi berlangsung, juga diperlukan agen hayati lain yaitu kelompok bakteri yang dapat menunjang kinerja fitoremediasi. Kelompok bakteri tersebut diantaranya bakteri yang bersifat pemfiksasi $\mathrm{N}$ dan penyedia Fosfor (P). Nitrogen dan Fosfor adalah senyawa vital yang diperlukan tanaman fitoremediator hidrokarbon limbah minyak bumi.

Peranan unsur $P$ antara lain penting untuk pertumbuhan sel, pembentukan akar halus dan rambut akar, memperkuat batang agar tanaman tidak mudah rebah, memperbaiki kualitas tanaman, pembentukan bunga, buah dan biji, serta memperkuat daya tahan terhadap penyakit. Sedangkan fungsi $\mathrm{N}$ adalah memperbaiki pertumbuhan vegetatif tanaman. Tanaman yang tumbuh pada tanah cukup $\mathrm{N}$, berwarna lebih hijau. Unsur $\mathrm{N}$ juga beperan dalam pembentukan protein (Hardjowigeno, 2003). Pada tanah terkontaminasi hidrokarbon, unsurunsur hara tersebut akan sulit diserap oleh 
tanaman karena tidak tersedia atau tidak terlarut untuk tanaman. Maka penambahan kultur Azotobacter sp. sebagai bakteri penambat nitrogen dan penghasil fitohormon diharapkan dapat meningkatkan pertumbuhan tanaman. Penambahan kultur Pseudomonas sp. sebagai bakteri pelarut fosfat juga dapat meningkatkan unsur P menjadi lebih tersedia bagi tanaman. Penambahan dua agen hayati tersebut merupakan strategi pengembangan dari konsep fitoremediasi hidrokarbon minyak bumi.

Kedua bakteri yang diaplikasikan dalam penelitian ini memiliki persamaan sebagai penghasil fitohormon. Kemampuan Azotobacter sp. dalam mengubah $\mathrm{N}_{2}$ menjadi $\mathrm{NH}_{3}$ yang dapat dimanfaatkan oleh organisme lain. Bakteri penambat $\mathrm{N}_{2}$ genus Azotobacter sp. juga dapat meningkatkan kesehatan tanah karena mampu menyediakan amonium yang dapat meningkatkan kesuburan tanah (Hindersah dan Simarmata 2004). Jnawali et. al. (2015) melapokan bahwa peran Azotobacter sp. selain sebagai pemfiksasi Nitrogen juga berperan dalam memproduksi senyawasenyawa untuk mendukung pertumbuhan, diantaranya: thiomin, riboflavin, nicotin, Indol Acetic Acid (IAA) dan giberalin (GA). Selain itu Azotobacter sp. juga dapat menghasilkan biosurfaktan yang dapat meningkatkan kelarutan hidrokarbon (Suryatmana et. al., 2018). Efektifitas bakteri pelarut fosfat tidak hanya dipertimbangkan oleh kemampuannya dalam meningkatkan ketersediaan $\mathrm{P}$ tetapi juga kemampuannya dalam menghasilkan zat pengatur tumbuh seperti asam indol asetat (IAA) dan asam giberelin (GA3) (Patten dan Glick, 1996).

Berdasarkan karakteristik spesiesnya, bakteri yang digunakan merupakan kombinasi yang tepat yang dapat diharapkan untuk menunjang aktivitas petrofilik indigenous yang berada di sekitar rizosfir sorgum sebagai pendegradasi senyawa hidrokarbon. Selain itu, kedua bakteri dapat menunjang kinerja tanaman sorgum sebagai tanaman fitoremediator hidrokarbon minyak bumi. Penggunaan sorgum sebagai agen fitoremediasi hidrokarbon minyak bumi yang dikombinasikan dengan kultur Azotobacter sp. dan Pseudimonas sp. merupakan strategi yang tepat untuk meningkatkan kinerja fitoremediasi hidrokarbon minyak bumi oleh tanaman sorgum.

Tujuan dari penelitian ini adalah menganalisa kemampuan tanaman sorgum sebagai agen fitoremediasi hidrokarbon minyak bumi dan kemampuan agen hayati Azotobacter sp dan Pseudomonas sp. dalam meningkatkan efisiensi biodegradasi hidrokarbon, pertambahan tinggi tanaman sorgum dan kemampuan adatasi kedua spesies tersebut sebagai agen biologis dalam kondisi tanah yang tercekam toksik hidrokarbon.

\section{METODOLOGI}

\subsection{Rancangan Percobaan}

Rancanagan penelitian yang digunakan adalah Rancangan Acak Kelompok (RAK) pola faktorial yang terdiri atas dua faktor, yaitu dosis Azotobacter sp dan Pseudomonas sp. Berikut adalah rancangan percobaan yang digunakan dalam penelitian ini:

Faktor I: dosis Azotobacter sp. (A)

$\mathrm{a}_{0}=$ tanpa pemberian Azotobacter sp.

$\mathrm{a}_{1}=$ Azotobacter sp. $1 \% /[\mathrm{TPH}](\mathrm{v} / \mathrm{w})$

$\mathrm{a}_{2}=$ Azotobacter sp. $2 \% /[\mathrm{TPH}](\mathrm{v} / \mathrm{w})$

$\mathrm{a}_{3}=$ Azotobacter sp. $3 \% /[\mathrm{TPH}](\mathrm{v} / \mathrm{w})$

Faktor II : Dosis Pseudomonas sp. (B)

$\mathrm{b}_{0}=$ tanpa pemberian Pseudomonas sp.

$\mathrm{b}_{1}=$ Pseudomonas sp. $1 \% /[\mathrm{TPH}](\mathrm{v} / \mathrm{w})$

$\mathrm{b}_{2}=$ Pseudomonas sp. $2 \% /[\mathrm{TPH}](\mathrm{v} / \mathrm{w})$

$\mathrm{b}_{3}=$ Pseudomonas sp. $3 \% /[\mathrm{TPH}](\mathrm{v} / \mathrm{w})$

\subsection{Perbanyakan Inokulan Bakteri}

Perbanyakan inokulan Azotobacter sp. dilakukan di Laboratorium Biologi dan Bioteknologi Tanah, Departemen Ilmu Tanah dan Sumber Daya Lahan, Fakultas Pertanian Universitas Padjadjaran. Media yang digunakan untuk perbanyakan inokulan Azotobacter sp. adalah molase $2 \%$ dan media untuk Pseudomonas sp. adalah media cair pikovskaya. Isolat starter masing-masing $10 \%$ dari volume media, diinkubasi selama 72 jam pada suhu ruang dengan pengocokan $100 \mathrm{rpm}$. 


\subsection{Penanaman dan Pemeliharaan Tanaman Sorgum}

Benih sorgum yang digunakan terlebih dahulu direndam menggunakan air selama 24 jam untuk mematahkan masa dormansi benih hingga muncul bakal akar. Media tumbuh untuk tanaman sorgum yang digunakan berupa campuran tanah mineral (Inceptisol) sebanyak 10 kg dengan kompos sebagai pupuk dasar dengan dosis $25 \mathrm{~g}$ per pot. Media tanam tersebut kemudian diinkubasikan selama 7 (tujuh) hari.

Perlakuan spesies Azotobacter sp. dan Pseudomonas sp. dilakukan dengan dicampurkan ke dalam hidrokarbon minyak bumi yang telah diinkubasikan selama 1 (satu) hari. Hidrokarbon yang telah diberi inokulan diaplikasikan pada media tanam dan diinkubasikan kembali selama 1 (satu) hari sebelum penanaman dan pemberian pupuk anorganik. Penanaman dilakukan setelah semua Persiapan selesai dan untuk benih yang ditanam adalah 1 benih per pot.

Pupuk anorganik yang digunakan adalah: Urea, SP36 dan $\mathrm{KCl}$ hanya diberikan $1 / 2$ dari dosis anjuran Departemen Pertanian. Pemeliharaan tanaman sorgum yang dilakukan selama penelitian berlangsung meliputi: penyiraman sampai kapasitas lapang dan penyiangan gulma.

\subsection{Analisis residu TPH, populasi Bakteri dan Pertumbuhan Tanaman}

Pengamatan residu TPH dilakukan dengan metode gravimetrik menggunakan pelarut $\mathrm{n}$ Heksan. Pengukuran TPH dilakukan pada awal dan akhir penelitian. Pengukuran TPH ini dilakukan dengan cara mengambil sampel dari tiap pot percobaan sebanyak $5 \mathrm{~g}$. Sample tanah percobaan dimasukan ke dalam botol kocok dan ditambahkan $10 \mathrm{ml}$ n-Heksan, selanjutnya dilakukan pengocokan selama 60 menit pada alat pengocok (shaker), maka diperoleh ektrak TPH yang terlarut di dalam n-Heksan.

Ekstrak TPH dituangkan ke dalam botol sample penampung yang telah ditimbang terlebih. Sample TPH dalam botol vial diuapkan sampai n-Hexan hilang dan ditimbang. Persen TPH hasil ekstraksi adalah selisih berat botol yg mengandung TPH dikurangi berat botol kosong (awal) per berat sample tanah dikali $100 \%$.

Perhitungan populasi Azotobacter spp. dan Peudomonas spp. dilakukan dengan menggunakan metode total plate count (TPC) dalam media padat ashby dan pycovskaya termodifikasi yaitu ditambahkan $1 \%$ hidrokarbon. Pengukuran pertumbuhan tanaman berupa tinggi tanaman dilakukan dengan menggunakan alat ukur (mistar/meteran).

Pengamatan pertumbuhan tanaman sorgum dilakukan pada awal dan akhir penelitian. Pengukuran pertumbuhan tanaman berupa tinggi tanaman dilakukan dengan menggunakan alat ukur (mistar/meteran). Pengamatan setiap parameter uji dilakukan pada minggu ke-14 setelah tanam (14 MST) dan setelah proses biodegradasi berlangsung berlangsung.

\section{HASIL DAN PEMBAHASAN}

\subsection{Efisiensi Degradasi Hidrokarbon}

Hasil analisi menunjukkan bahwa aplikasi antara Azotobacter sp. dengan Pseudomonas sp. terhadap efisiensi degradasi hidrokarbon tidak menunjukan efek interaksi. Pengaruh mandiri dari masing-masing perlakuan juga tidak menunjukkan hasil yang signifikan antar perlakuan (Tabel 1).

Tabel 1 Pengaruh Azotobacter sp. dan Pseudomonas sp. terhadap efisiensi degradasi hidrokarbon pada 14 MST

\begin{tabular}{|c|c|}
\hline Perlakuan & $\begin{array}{c}\text { Efisiensi } \\
\text { Degradasi } \\
\text { Hidrokarbon } \\
(\%)\end{array}$ \\
\hline \multicolumn{2}{|l|}{ Azotobacter (A) } \\
\hline $\mathrm{a}_{0}=$ Tanpa Azotobacter & $68,165 \mathrm{a}$ \\
\hline $\mathrm{a}_{1}=1 \%$ Azotobacter $\mathrm{sp}$. & $66,656 a$ \\
\hline $\mathrm{a}_{2}=2 \%$ Azotobacter sp. & $62,260 \mathrm{a}$ \\
\hline $\mathrm{a}_{3}=3 \%$ Azotobacter sp. & $63,817 \mathrm{a}$ \\
\hline \multicolumn{2}{|l|}{ Pseudomonas(B) } \\
\hline $\mathrm{b}_{0}=$ Tanpa Pseudomonas sp. & $60,423 \mathrm{a}$ \\
\hline $\mathrm{b}_{1}=1 \%$ Pseudomonas sp. & $61,317 \mathrm{a}$ \\
\hline $\mathrm{b}_{2}=2 \%$ Pseudomonas sp. & $72,613 \mathrm{a}$ \\
\hline $\mathrm{b}_{3}=3 \%$ Pseudomonas sp. & $66,546 \mathrm{a}$ \\
\hline
\end{tabular}


Aplikasi Azotobacter sp. dengan Pseudomonas sp. tidak berinteraksi terhadap efisiensi degradasi hidrokarbon, hal ini disebabkan karena kultur Azotobacter sp. tidak dapat berasosiasi positif dengan kultur Pseudomans sp. di dalam tanah percobaan. Faktor lain yang dipertimbangkan adalah kemungkinan kemampuan adaptasi Azotobacter sp. dan Pseudomonas sp. yang rendah pada kondisi lingkungan toksik pada saat pengukuran (14 MST). Hal ini dapat dilihat dari hasil analisis pada minggu ke 14 dimana masih tersisa hidrokarbon yang resisten. Sehingga keberadaan kedua spseies dalam satu sistem tanah terkontamnasi mengalami penurunan kepadatan populasi sehingga tidak menunjukan interaksi yang signifikan diantara kedua spesies tersebut. Seperti yang dijelaskan Suryatmana et. al. (2018) bahwa viabilitas bakteri dalam polutan minyak bumi mengalami penurunan populasi yang signifikan sampai akhir proses biodegradasi diakibatkan dihasilkannya residu senyawa antara yang bersifat resisten dan toksik. Dengan demikian semakin tinggi kemampuan bakteri dalam mendegradasi hidrokarbon minyak bumi, maka viabilitas bakteri akan semakin baik, walaupun pola pertumbuhan bakteri akan berjalan lebih lambat.

Aktivitas Azotobacter sp. pada kondisi lingkungan toksik akan mengalami penuruan kapasitas dalam menghasilkan fitohormon, juga dalam memfiksasi $\mathrm{N}$, sehingga mengakibatkan kontribusi Azotobacter sp. dalam memasok $\mathrm{N}$ dan Fitohormon bagi tumbuhan Sorgum juga tidak signifikan. Akibatnya, pertumbuhan akar tanaman dan produksi eksudat akar yang meliputi gula, asam amino, asam organik, asam lemak, sterol, nukleotida, flavanones, enzim, dan senyawa lain yang dieksresikan rendah (Shimp et. al., 1993). Akibat rendahnya senyawa-senyawa esensial dari eksudat akar yang dibutuhkan Azotobacter spp, Pseudomonas sp. dan petrofilik indigenous juga tidak memadai untuk memacu aktifitas mikroba petrofilik dalam mendukung proses degradasi hidrokarbon minyak bumi. Oleh karena itu, penambahan Azotobacter sp. tidak berbeda nyata dengan perlakuan tanpa
Azotobacter sp. terhadap nilai efefiensi biodegradasi pada akhir pengamatan.

Penambahan Pseudomonas sp. tidak menunjukkan nilai yang signifikan, akan tetapi inokulasi Pseudomonas sp. cenderung berpotensi dalam meningkatkan degradasi hidrokarbon, hal ini karena Pseudomonas sp. mampu menggunakan senyawa karbon yang terkandung di dalam hidrokarbon. Hasil tersebut sesuai dengan penelitian Udiharto (1992) bahwa Pseudomonas sp. mendominasi lingkungan yang sering terkena tumpahan minyak bumi di sekitar Pelabuhan Pertamina Tanjung Priok. Setelah diadaptasikan dan diaktifkan dalam media terlihat bahwa Pseudomonas sp. merupakan spesies bakteri yang mempunyai kemampuan dalam mendegradasi minyak bumi. Hasil analisis juga menunjukan bahwa pada 14 MST Pseudomonas sp. juga perlu melakukan adaptasi dalam memanfaatkan senyawa karbon resisten yang tersisa sehingga senyawa "antara" hasil degradasi hidrokarbon yang akan dimanfaatkan oleh Pseudomonas sp. untuk pertumbuhannya menjadi kurang tersedia, akibatnya Pseudomonas sp. tidak mampu menstimulasi dan meningkatkan efisiensi biodegradasi hidrokarbon minyak bumi secara signifikan.

Hasil investigasi data terhadap perlakuan tanpa Azotobactersp. maupun tanpa Pseudomonas sp. (kontrol) menunjukkan bahwa petrofilik indigenus memiliki kemampuan degradasi hidrokarbon minyak bumi pada rentang 60,423 - 68,165\%. Hal ini menunjukkan bahwa keberadaan petrofilik indigenus di dalam tanah percobaan berpotensi mampu menggunakan senyawa hidrokarbon minyak bumi sebagai sumber karbonnya. Munawar (2012) menjelaskan bahwa agen biologis indigenous mempunyai kemampuan biodegradasi lebih tinggi dibandingkan dengan agen biologis komersial.

Biodegradasi minyak mentah oleh agen biologis komersial hanya mampu mendegradasi 0,1 - $18 \%$, sedangkan biodegradasi minyak mentah menggunakan agen biologis indigenous mampu mendegradasi 16 - 25\% dalam waktu yang sama. Hal senada diungkap- 
kan oleh Van Eyk (1997) bahwa secara alami sebenarnya biodegradasi hirokarbon minyak bumi terjadi akibat adanya aktivitas mikroorganisme indigenus yang mampu memanfaatkan hidrokarbon minyak bumi sebagai sumber karbon dan energinya, walaupun proses tersebut berlangsung sangat lambat. Kondisi ini terjadi karena adanya senyawa hidrokarbon dengan tingkat toksisitas tinggi dan bersifat resisten seperti senyawa polisiklik aromatik hidrokarbon.

\subsection{Total Populasi Bakteri Azotobacter sp. dan Pseudomonas sp.}

Hasil analisis menunjukkan bahwa tidak terjadi interaksi antara Azotobacter sp. dan Pseudomonas sp. terhadap total populasi Azotobacter sp. maupun total populasi bakteri Pseudomonas sp. selama proses fitoremediasi hidrokarbon minyak bumi berlangsung selama 14 minggu. Total populasi Azotobacter sp. dan total populasi bakteri Pseudomonas sp. pada berbagai perlakuan disajikan pada Tabel 2 .

Tabel 2 Pengaruh Azotobacter sp. dan Pseudomonas sp. dalam proses fitoremediasi hidrokarbon minyak bumi terhadap populasi bakteri Azotobacter sp.

\begin{tabular}{|c|c|c|}
\hline Perlakuan & $\begin{array}{c}\text { Populasi } \\
\text { Pseudomonas sp. } \\
\text { (1066 CFU/gram) }\end{array}$ & $\begin{array}{c}\text { Populasi } \\
\text { Azotobacter sp. } \\
\text { (105CFU/gram) }\end{array}$ \\
\hline \multicolumn{3}{|l|}{ Azotobacter (A) } \\
\hline $\mathrm{a}_{0}=$ Tanpa Azotobacter sp. $/ \mathrm{TPH}(\mathrm{v} / \mathrm{w})$ & $653,75 \mathrm{a}$ & $486,67 \mathrm{a}$ \\
\hline $\mathrm{a}_{1}=1 \%$ Azotobacter sp. $/ \mathrm{TPH}(\mathrm{v} / \mathrm{w})$ & $633,75 \mathrm{a}$ & $597,08 \mathrm{a}$ \\
\hline $\mathrm{a}_{2}=2 \%$ Azotobacter sp. $/ \mathrm{TPH}(\mathrm{v} / \mathrm{w})$ & $727,08 \mathrm{a}$ & 608,33 a \\
\hline $\mathrm{a}_{3}=3 \%$ Azotobacter sp. $/ \mathrm{TPH}(\mathrm{v} / \mathrm{w})$ & $629,58 \mathrm{a}$ & $499,58 \mathrm{a}$ \\
\hline \multicolumn{3}{|l|}{ Pseudomonas (B) } \\
\hline $\mathrm{b}_{0}=$ Tanpa Pseudomonas sp. $/ \mathrm{TPH}(\mathrm{v} / \mathrm{w})$ & $616,67 \mathrm{a}$ & $485,00 \mathrm{a}$ \\
\hline $\mathrm{b}_{1}=1 \%$ Pseudomonas sp. $/ \mathrm{TPH}(\mathrm{v} / \mathrm{w})$ & 677,5 a & $580,00 \mathrm{a}$ \\
\hline $\mathrm{b}_{2}=2 \%$ Pseudomonas sp. $/ \mathrm{TPH}(\mathrm{v} / \mathrm{w})$ & $707,92 \mathrm{a}$ & $525,42 \mathrm{a}$ \\
\hline $\mathrm{b}_{3}=3 \%$ Pseudomonas sp. $/ \mathrm{TPH}(\mathrm{v} / \mathrm{w})$ & $642,08 \mathrm{a}$ & $601,25 \mathrm{a}$ \\
\hline
\end{tabular}

Keterangan: Angka yang diikuti huruf yang sama tidak berbeda nyatamenurut uji jarak berganda Duncan pada taraf $5 \%$.

Pengaruh mandiri Azotobacter sp. dan Pseudomonas sp. tidak berbeda nyata antara masing-masing perlakuan, baik terhadap total populasi Azotobacter spp. maupun terhadap total populasi bakteri Pseudomonas spp. Hasil analisis menunjukkan bahwa dengan penambahan Azotobacter sp. dengan variasi konsentrasi kepadatan tidak menunjukkan peningkatan yang signifikan terhadap populasi Pseudomonas sp. dan Azotobacter sp. dalam tanah percobaan. Namun, aplikasi Azotobacter sp. cenderung meningkatkan populasi Pseudomonas spp. pada perlakuan 1\%. dan meningkatkan populasi Azotobacter sp. pada semua dosis perlakuan.

Aplikasi Psedomonas sp. dengan variasi konsentrasi juga belum mampu meningkatkan populasi Psedomonas sp. dan Azotobacter sp. secara signifikan. Hal ini tampak dari populasi Azotobacter spp. dan Pseudomonas sp. indigenus pada perlakuan kontrol tidak berbeda nyata dengan perlakuan lainnya. Hal ini terjadi akibat kedua spesies eksogenous yang diaplikasikan belum mampu berdaptasi dengan baik pada kondisi cekaman toksik. Pada kondisi ini terjadi residu hidrokarbon yang sulit terdegradasi dan kemungkinan terjadi senyawa antara yang lebih toksik. Oleh karena itu, populasi Azotobacter sp. maupun Pseudomonas spp. mengalami perlambatan pertumbuhan. Hal ini sejalan dengan Suryatmana et. al. (2018) dimana pada hari ke-42 proses bioremediasi minyak bumi dihasilkan residu hidrokarbon di dalam tanah yang didominsi oleh hidrokarbon yang sulit terdegradasi yaitu senyawa-senyawa aromatik antara lain: siklohexaciloksan, dodecametyl, tetradeca-metyl, sikloheksasiloksan, dan sikloheptasiloksan.

Senyawa senyawa hidrokarbon aromatik kemungkinan besar mampu menekan pertumbuhan Azotobacter sp. maupun Pseudomonas sp. karena bersifat toksik dan sulit terdegra- 
dasi. Kondisi pada minggu ke 14 dari percobaan ini juga mengalami hal yang sama yaitu tersisa senyawa hidrokarbon yang sulit terdegradasi dan sumber karbon bagi Azotobacter sp. dan Pseudomonas sp. juga sudah sangat rendah. Jika sumber karbon dan energi tidak mencukupi maka aktivitas bakteri pun akan terhenti. Hal ini terlihat pada hasil analisis yang menunjukkan populasi Azotobacter sp dan Pseudomonas sp. yang tidak mengalami peningkatan walaupun konsentrasi kultur ditingkatkan. Hal tersebut menunjukkan kemampuan adapatasi dari kedua spesies bioagen yang digunakan masih tergolong rendah menghadapi tekanan cekaman toksis hidrokarbon di dalam tanah akibat adanya residu hidrokarbon yang tidak dapat digunakan sebagai sumber karbon kedua bakteri tersebut.

\subsection{Tinggi Tanaman pada 14 MST}

Perlakuan aplikasi Azotobacter sp. dengan Pseudomonas sp. tidak berpengaruh nyata terhadap tinggi tanaman Sorgum yang digunakan sebagai agen fitoremediator hidrokarbon minyak bumi. Demikian pula perlakuan secara mandiri tidak menunjukan perbedaan yang nyata antar dan tidak berpengaruh nyata terhadap tinggi tanaman pada 14 MST dan selama proses fitoremediasi berlangsung (Tabel 3).

Tabel 3 Pengaruh Azotobacter sp. dengan Pseudomonas sp. tinggi tanaman sorgum $14 \mathrm{MS}$

\begin{tabular}{lc}
\hline \multicolumn{1}{c}{ Perlakuan } & $\begin{array}{c}\text { Tinggi } \\
\text { tanaman }(\mathrm{cm})\end{array}$ \\
\hline Azotobacter $(\mathrm{A})$ & $11,192 \mathrm{a}$ \\
$\mathrm{a}_{0}=$ Tanpa Azotobacter & $9,125 \mathrm{a}$ \\
$\mathrm{a}_{1}=1 \%$ Azotobacter $\mathrm{sp}$. & $8,083 \mathrm{a}$ \\
$\mathrm{a}_{2}=2 \%$ Azotobacter $\mathrm{sp}$. & $8,842 \mathrm{a}$ \\
$\mathrm{a}_{3}=3 \%$ Azotobacter $\mathrm{sp}$. & \\
\hline Pseudomonas $(\mathrm{B})$ & \\
$\mathrm{b}_{0}=$ Tanpa Pseudomonas $\mathrm{sp}$. & $10,708 \mathrm{a}$ \\
$\mathrm{b}_{1}=1 \%$ Pseudomonas sp. & $5,883 \mathrm{a}$ \\
$\mathrm{b}_{2}=2 \%$ Pseudomonas $\mathrm{sp}$. & $11,150 \mathrm{a}$ \\
$\mathrm{b}_{3}=3 \%$ Pseudomonas sp. & $9,500 \mathrm{a}$ \\
\hline Keterangan: Nilai rata-rata yang diikuti huruf yang \\
\multicolumn{2}{c}{ sama tidak berbeda nyata menurut uji } \\
jarak berganda Duncan pada taraf $5 \%$.
\end{tabular}

Hasil analisis menunjukkan bahwa aplikasi Azotobacter sp. eksogenous tidak mampu meningkatkan tinggi tanaman sorgum selama proses fitoremediasi hidrokarbon. Bahkan tampak bahwa tinggi tanamn sorgum yang diinokulasi dengan Azotobacter sp. eksogenous cenderung lebih rendah dibandingakan kontrol. Hal yang sama terjadi pada pengaruh mandiri akibat aplikasi Pseudomonas sp. juga tidak menunjukkan peningkatan tinggi tanaman sorgum. Hal ini diakibatkan pada fase biodegradasi akhir dihasilkan senyawa residu hidrokarbon yang resisten (Suryatmana et al., 2018) dan bersifat lebih toksik. Akibatnya kultur bioagen eksogenous yang diinokulasikan mengalami penuruan populasi dan aktivitas stimulasinya dalam mensuplay $\mathrm{N}$ dan fitohormon bagi pertumbuhan sorgum, sehingga tampak bahwa keberadaan Azotobacter sp. maupun Pseudomonas sp. eksogenous tidak memberikan kontribusi yang nyata dalam menstimulasi pertumbuhan sorgum.

Hasil analisis terhadap pertumbuhan menunjukkan peningkatan dosis Azotobacter sp. justru mengakibatkan kecenderungan penurunan tinggi tanaman. Hal ini menunjukkan bahwa terjadi persaingan sumber karbon dan nutrisi antar populasi Azotobacter sp. di dalam tanah percobaan. Pada kondisi tekanan toksis yang tinggi terjadi penurunan kinerja dari Azotobacter sp. dalam memfiksasi N, dan menghasilakan fitohormon dan pula terhambatnya kinerja Pseudomonas sp. sebagai biostimulan bagi tanaman sorgum.

Peran Azotobacter sp. yang diaplikasikan (eksogenous) yang tidak optimal sejalan dengan pendapat Rao (1994) bahwa penggunaan Azotobacter sp. dapat memberikan hasil yang bervariasi mulai dari tidak ada pengaruh secara signifikan sampai meningkatkan pertumbuhan secara signifikan. Pada penelitian ini inokulasi Azotobacter sp. maupun Pseudomonas sp. tidak berpengaruh terhadap peningkatan tinggi tanaman sampai minggu ke 14 MST. Pertumbuhan tanaman sorgum pada 14 MST tampaknya mengalami hambatan pertumbuhan akibat berada dalam cekaman toksik hidrokabon minyak bumi di dalam tanah (Gambar 1). 

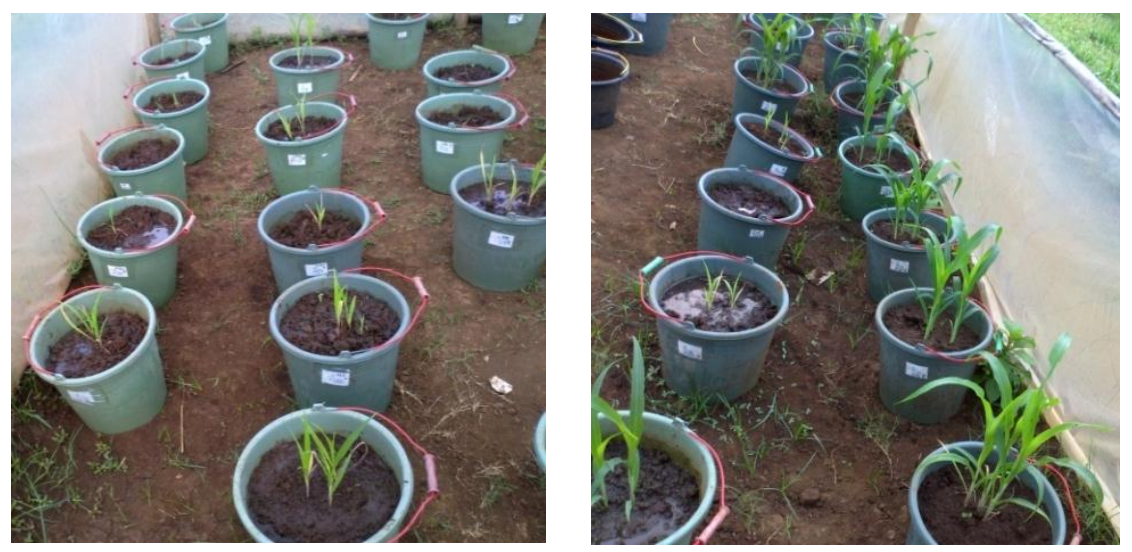

Gambar 1 Pertumbuhan tanaman sorgum pada 14 MST pada kondisi tanah terkontaminasi minyak bumi dalam proses fitoremediasi mengalami hambatan pertumbuhan

\section{KESIMPULAN}

Aplikasi Azotobacter sp. dan Pseudomonassp. dalam proses Fitoremediasi limbah minyak bumi oleh tanaman Sorgum tidak menunjukkan stimulasi yang dapat meningkatkan efisiensi degradasi hidrokarbon minyak bumi, populasi Azotobacter spp., populasi Pseudomonas spp. dan pertambahan tinggi tanaman Sorgum. Kedua spesies tidak menunjukkan interaksi terhadap efisiensi biodegradasi, tinggi tanaman Sorgum dan populasi Azotobacter sp. dan Pseudomonas sp. Bakteri eksogenous yang digunakan dalam proses Fitoremediasi cenderung tidak mampu beradaptasi dengan maksimal dalam cekaman toksik oleh adanya senyawa polutan hidrokarbon minyak bumi di dalam tanah, sehingga belum mampu meningkatkan pertambahan tinggi tanaman Sorgum. Tinggi tanaman Sorgum yang diberi Azotobacter sp. menunjukkan kecenderungan lebih rendah dibandingkan perlakuan kontrol.

Azotobacter spp. dan Pseudomonas spp. indigenus memiliki potensi lebih tinggi dalam menstimulasi pertumbuhan tanaman sorgum dan nilai efisiensi biodegradasi hidrokarbon minyak bumi oleh tanaman Sorgum. Efisiensi biodegradasi hidrokarbon minyak bumi dalam proses Fotoremediasi oleh Sorgum ini pada perlakuan kontrol (Azotobcter spp dan Pseudomonas spp. indigenus) berkisar pada rentang nilai $60,423 \%$ - 68,165\% selama waktu 14 minggu.

\section{Ucapan Terimaksih}

Terima kasih kepada Kementerian Pendidikan Tinggi (DIKTI) yang telah mendanai penelitian ini pada implementasi skema program Penelitian Dasar Unggulan Perguruan Tinggi (PDUPT) tahun anggaran 2019-2020, serta terimaksih pada Kepala Laboratorium Biologi Tanah Departemen Ilmu Tanah, Universitas Padjadjaran yang telah membantu menyediakan fasilitas laboratorium selama masa penelitian berlangsung.

\section{DAFTAR PUSTAKA}

Atlas, R. M. and R. Bartha. 1998. Microbial Ecology: Fundamentals and Application. Benjamin/Cummings Publishing Company. California.

Badan Pusat Statistik. 2018. Produksi Minyak Bumi dan Gas alam 1996-2018. Diakses, 6 Maret 2020.https://www.bps.go.id/statictab le/2009/06/15/1092/produksiminyak-bumi-dan-gas-alam-19962018.html.

Doerffer, J. W. 1992. Oil Spill Response in the Marine Environment. First Edition. Pergamon Press. Oxford, UK.

Hardjowigeno, S. 2003. Ilmu Tanah. Akademika Pressindo, Jakarta.

Hindersah, R. dan Simarmata, T. 2004. Potensi rhizobakteri Azotobacter dalam meningkatkan kesehatan tanah. Jurnal Natur Indonesia. 5(2): 127-133. 
Jnawali, A. D., R. B. Ojha and S. Marahatta. 2015. Role of azotobacter in soil fertility and sustainability-a review. Advances in Plants \& Agriculture Research, 2 (6): $250-253$.

Kementerian Lingkungan Hidup Republik Indonesia. 2003. Keputusan Menteri Negara Lingkungan Hidup Nomor 128 Tahun 2003 Tentang Tata Cara dan Persyaratan Teknis Pengolahan Limbah Minyak Bumi dan Tanah Terkontaminasi Limbah Minyak Bumi secara Biologis. Kementrian Lingkungan Hidup. Jakarta.

Munawar. 2012. Bioremediasi Tanah Terkontaminasi Minyak Bumi Oleh Konsorsium Bakteri Petrofilik, Penambat Nitrogen dan Pelarut Fosfat. Institut Teknologi Bandung. [Disertasi].

Patten, C. L and Glick, B.R.1996. Bacterial biosyntesis of indole-3-acectic acid. Can. J. Microbiol 42(3):207-220.

Rao, N. S. S. 1994. Mikroorganisme Tanah dan Pertumbuhan Tanaman. Jakarta: UIPress.

Salt, D. E., R. D. Smith and I. Raskin. 1998. Phytoremediation- annual review Plant Physiology and Plant Molecular Biology. 49: 643-668.

Shimp, J. F., J. C. Tracy, L. C. Davis, E. Lee, W. Huang, L. E. Erickson, and L. J. Schnoor. 1993. Beneficial effects of plants in the remediation of soil and groundwater contaminated with organic materials. Critical Reviews in Environmental Science and Technology. 23(1): 41 77.

Suryatmana, P., A. M. Zannatan, A. R. Sylvia, M. R. Setiawati, Syafrizal, Zulkifliani, A. P. Wulandari and A. Riztama. 2018. Bioremediation of petroleum contaminated soil using oyster mushroom log waste (OMLW), Azotobacter vinelandii, and a petrophylic consortium. Asian Jr. of Microbiol. Biotech. Env. Sc. 20 (October Suppl.): 158-168.

Thomas, J. M., C. H. Ward, R. L. Raymond, J. T. Wilson, and R. C. Lohehr. 1992. Bioremediation. In Ledrberg, J. (Ed.). Encyclopedia of Microbiology. Academic Press. London.
Truu, M., J. Truu and M. Ivask, 2008. Soil microbiological and biochemical properties for assessing the effect of agricultural management practices in Estonian cultivated soils. Eur. J. Soil Biologi, 44(2): 231-237.

Udiharto, M. 1992. Aktivitas mikroba dalam degradasi crude oil. Dalam Prosiding Diskusi Ilmiah VII Hasil Penelitian Pusat Penelitian dan Pengembangan Teknologi Minyak dan Gas Bumi (PPPTMGB); Cibinong, 13-14 Jun 1992.

Van Eyk, J. 1997. Petroleum Bioventing. A.A. Balkema. Rotterdam, Netherlands.

Widyati, E. 2008. Peranan mikroba tanah pada kegiatan rehabilitasi lahan bekas tambang (Roles microbes in ex-mining land rehabiltation). Jurnal Info Hutan, 5(2): 151-160.

Young, L. Y., J. Kazumi, C. Phelps, dan C. M. So. 1996. Anaerobic transportation of aromatic and aliphatic hydrocarbons. In Enviromental Biotechnology, EC-US Task Force on Biotechnology Reasearch. p: $10-11$. 